\author{
Andriy $V$. Botsman \\ orcid.org/0000-0003-3083-6637 \\ Olga V. Dmytruk \\ orcid.org/0000-0002-7540-7708
}

\title{
GERMANIC PRETERITE-PRESENT VERBS AND THEIR MORPHOLOGICAL AND SEMANTIC PECULIARITIES
}

\begin{abstract}
The purpose of this article is to give detailed description to all possible semantic and morphological features of Germanic preteritepresent verbs. Some research has dealt with the problem of preteritepresent present verbs; however, semantic and morphological functions of these verbs were studied only by singling out verb characteristics, peculiarities, potential possibilities in different Germanic languages without any alignment of the obtained results. There is little information available on preterite-present verbs within the west Germanic and North Germanic (Scandinavian) subgroups. Semantic aspect of these verbs was analysed by some scholars, but it is still unknown how these verbs were formed in other Indo-European languages (Baltic, Slavonic, Romantic). The contradicting point of the available research is how those verbs are reflected in Latin and Greek. In spite of the fact that preterite-present verbs were studied in detail in terms of phonological characteristics, their morphological and semantic peculiarities were not taken into account and compared. Special attention should be given to the functioning and correlation of phonological and morphological peculiarities of those verbs. This paper offers the results of a detailed and consistent analysis of phonological and morphological peculiarities of preterite-present verbs. The paper aims at determining the morphological characteristics of preterite-present verbs, which were formed under the influence of phonological processes. The purpose of this study was to investigate the connection of Germanic preterite-present verbs with possible sources in other Indo-European languages. The authors define a set of characteristics peculiar of preterite-present verbs semantics. The functions of these verbs are analysed in detail. The authors attempt to analyse the nature of these verbs. The attention is paid to the functions of preterite- present verbs not only in the Germanic languages, but in other Indo-European languages, too. The comparative historical method is used
\end{abstract}


here as the main one. The authors see this valid way of investigation as reliable and appropriate for the preterite-present verb analysis.

Key words: consonant shift, preterite-present verbs, verb derivative semantics, verb semantics, vowel gradation.

Information about authors: Botsman Andriy Vasylovych - PhD in Chemistry, Ph.D. in English Philology, Associate Professor; Associate Professor of the Department of English Philology and Intercultural Communication; Institute of Philology; Taras Shevchenko National University of Kyiv.

Dmytruk Olga Viktorivna - PhD in English Philology, Associate Professor; Associate Professor of the Department of English Philology and Intercultural Communication; Institute of Philology; Taras Shevchenko National University of Kyiv.

E-mail: a.botsman@knu.ua; o.dmytruk@knu.ua

Боцман А. В.

orcid.org/0000-0003-3083-6637

Дмитрук О. В.

orcid.org/0000-0002-7540-7708

\section{ГЕРМАНСЬКІ ПРЕТЕРИТО-ПРЕЗЕНТНІ ДІССЛОВА ТА ЇХ МОРФОЛОГО-СЕМАНТИЧНІ ОСОБЛИВОСТІ}

Анотація. Статтю присвячено детальному опису морфологічних та семантичних характеристик германських претерито-презентних дієслів. Особливості функиіонування претерито-презентних дієслів у морфологічному ракурсі розглядалися низкою дослідників шлляхом виокремлення дієслівних характеристик, особливостей, потениійних можливостей у різних германських мовах. Однак, ие було зроблено без співставлення отриманих результатів. Існує доволі незначний обсяг достовірної інформації щяодо претерито-презентних дієслів у межах західногерманської та північногерманської (скандинавської) підгруп. Семантичний аспект ции дієслів був у фокусі уваги деяких авторів, але й досі невідомий шлях формування таких дієслів у інших індоєвропейських мовах (балтійських, слов'янських, романських). I досі залишається суперечливим питання про те, як иі дієслова відбилися у латинській та грецькій мовах. Незважаючи на той факт, що претерито-президенті дієслова були досліджені у деталях щодо фонологічних умов, їхні морфологічні та семантичні характеристики не були враховані та співставленні. Особлива увага у статті 
Актуальні проблеми української лінгвістики: теорія і практика

приділяється взаємозв'язку фонологічної та морфологічної специфіки ичих дієслів. $У$ статті описуються результати детального $i$ трунтовного порівняльного аналізу фонологічних, морфологічних $i$ семантичних особливостей претерито-презентних дієслів з метою визначення їх морфологічних характеристик, що сформувалися під впливом фонологічних прочесів. Метою дослідження $\epsilon$ виявлення зв'язків германських претерито-презентних дієслів з можливими джерелами в інших індоєвропейських мовах. Спектр характеристик наводиться в аспекті семантики даних дієслів, щчо уможливлює детально прослідкувати функціональне навантаження. Автори роблять спробу виявити природу иієї дієслівної групи. Приділено увагу дослідженню функиій претерито-презентних дієслів не лише у германських, а й інших індоєвропейських мовах. Провідним методом аналізу виступив порівняльно-історичний. Цей ефективний шлях дослідження є надійним та результативним для репрезентації фактів щодо специфіки претерито-презентних дієслів.

Ключові слова: градація голосних, дієслівна деривативна семантика, дієслівна семантика, зсув приголосних, претеритопрезентні дієслова.

Інформація про авторів: Боцман Андрій Васильович - кандидат хімічних наук, кандидат філологічних наук, доцент; доцент кафедри англійської філологї та міжкультурної комунікачії; Інститут філології; Київський начіональний університет імені Тараса Шевченка.

Дмитрук Ольга Вікторівна - кандидат філологічних наук, дочент; доцент кафедри англійської філології та міжкультурної комунікаиії; Інститут філологї; Київський національний університет імені Тараса Шевченка.

Електронна адреса: a.botsman@knu.ua; o.dmytruk@knu.ua

Боцман А. В.

orcid.org/0000-0003-3083-6637

Дмитрук О. В.

orcid.org/0000-0002-7540-7708

\section{ГЕРМАНСКИЕ ПРЕТЕРИТО-ПРЕЗЕНТНЫЕ ГЛАГОЛЫ И ИХ МОРФОЛОГО-СЕМАНТИЧЕСКИЕ ОСОБЕННОСТИ}

Аннотация. Статья посвящена детальному описанию
морфологических и семантических характеристик германских
претерито-презентных глаголов. Особенности функционирования 
претерито-презентных глаголов в морфологическом ракурсе рассматривались рядом исследователей путем выделения глагольных характеристик, особенностей, потенциальных возможностей в разных германских языках. Однако это было сделано без взаимного сравнения полученных результатов. Имеет место довольно незначительный объем достоверной информации о претеритопрезентных глаголах в рамках западногерманской и северогерманской (скандинавской) подгрупп. Семантический аспект этих глаголов был в центре внимания ряда лингвистов, однако на данный момент не выяснен путь формирования этих глаголов в других индоевропейских языках (балтийских, славянских, романских). До сих пор остается противоречивым вопрос о том, как эти глаголь отразились в латинском и греческом языках. Несмотря на тот факт, что претерито-презентные глаголь были детально исследованы в аспекте фонологии, их морфологический и семантические характеристики не были учтены и сопоставлены. Особое внимание авторы уделяют взаимосвязи фонологической и морфологической специфики этих глаголов. Эта статья описывает результать детального основательного сравнительного анализа фонологических, морфологических и семантических особенностей претеритопрезентных глаголов с иелью выделения их морфологических характеристик, которые сформировались под влиянием фонологических прочессов. Цель данного исследования - вылвление связей германских претерито-презентных глаголов с возможными источниками в других индоевропейских языках. Представлен также спектр семантических характеристик этих глаголов, а также детально проанализировань их функиии. Совершена попытка выяснить природу этой глагольной группы. Уделено внимание исследованию функиий претерито-презентные глаголов не только в германских, но и в других индоевропейских языках. Сравнительноисторический метод используется как основной инструмент исследования. Этот эффективный путь является надежным и результативным для представления фактов о специфике претеритопрезентных глаголов.

Ключевые слова: глагольная деривачионная семантика, глагольная семантика, градащия гласных, сдвиг согласных, претеритопрезентные глаголь.

Информация об авторах: Боиман Андрей Васильевич - кандидат химических наук, кандидат филологических наук, дочент; дочент кафедры английской филологии и межкультурной коммуникации; 
Актуальні проблеми української лінгвістики: теорія і практика

Институт филологии; Киевский национальный университет имени Тараса Шевченко.

Дмитрук Ольга Викторовна - кандидат филологических наук, дочент; доцент кафедры английской филологии и межкультурной коммуникаџии; Институт филологии; Киевский национальный университет имени Тараса Шевченко.

Электронный адрес: a.botsman@knu.ua; o.dmytruk@knu.ua

A comparatively small group of the so-called preterite-present verbs (there are 14 verbs with the modal semantic shade in the Germanic languages [14, p. 65-69]) is traditionally interesting for linguists as these verbs are characterised by specific development and further transformations [16, p. 142-147]. The Germanic verbs of this group represent originally unreduplicated perfects, which acquired a present meaning [18, p. 539]. Their forms of the present tense were not found, but the secondary forms of the past tense were formed involving pattern of the weak verbs. The secondary ones are also the forms of the infinitive, Participle I, Participle II. This verb type occurs in other Indo-European languages. These verbs represent the present tense meaning using the perfect forms. It means that they represent the result of the action that happened in the past. These are the following Indo-European verbs: L. meminī (I remember), ōdi (I

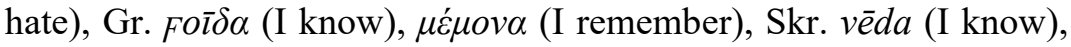
O Slav. ВБДБ (the form of perfect optative). There are no direct etymological relations between Germanic verbs of this type and the verbs of other Indo-European languages. There is only one exception: Gt. witan and, probably, munan [10, p. 274-275]. On the one hand, this verb group was separated in the Gothic language. This language is recognised as the oldest fact of written proof of these verbs in the Germanic languages. On the other hand, in the process of their relations and the development these verbs were losing their independence and undergone the process of grammaticalisation with the further analytical verb construction formation, and later they created grammatical forms of tense and mood.

The purpose of the article is to reveal common ancient roots in the system of Indo-European and Germanic preterite-present verbs. The investigation and identification of the ancients roots of certain 
lexico-semantic groups within the Indo-European language family is a very challenging task which needs comprehensive analysis and the reconstruction of the language parallels, which stipulates the topicality of the article. The scientific novelty of the research arises from the analysis which aims at removing layers which covered ancient roots of preterite-present verbs during the process of the separation of the Germanic languages from the IndoEuropean language family. The object of the investigation is Germanic preterite-present verbs, and related units of other ancient and modern Indo-European languages. The subject of the investigation is morpho-semantic peculiarities of the linguistic units in question. Consequently, the article is devoted to finding out and restoring common proto-roots of the preterite-present verbs and their derivatives.

Literature review. Approaches to the investigation of the Germanic preterite-present verbs are characterised by stable isolation of the traditional linguistic trends. Thus, the fundamental investigation of the verb cluster in the Gothic language is connected solely with morphology $[1, \mathrm{p} .134]$ or focuses on the conjugation paradigm [3, p. 165]. There were some controversial results of comparing present verbs with ablaut classes of strong verbs [5, p. 458]. The emphasis was placed on the development of modal verbs, their partial desemantisation and the development of their functions occurring during the whole history of the Germanic languages [8, p. 201]. There was an attempt to classify Gothic preterite-present verbs into corresponding vowel gradation classes. The result of this research was the gradual separation of those verbs from the Germanic strong verbs [12, p. 127]. The Indo-European verb is commonly characterised by the root maximum neutrality and flexibility, well-developed definite verb forms, highly developed verb system in general [13, p. 75]. However, preterite-present verbs, being integrated into the Indo-European language groundwork, are really valuable illustrations of ancient processes in the IndoEuropean language family, and, in particular, the separation of the Germanic languages from the Indo-European ancient proto-language. 
Results. The Germanic lexicon researchers state that two thirds of Germanic roots are of Indo-European origin [2, p. 35-36; 4, p. 88; 9, p. 45-47]. Preterite-present verb roots should be selected and analysed gradually, with individual separation, finding out IndoEuropean reflexions. The first verb to consider is witan (know). We should compare Gr. $\varepsilon i \delta \omega \varsigma<{ }^{*} F \varepsilon i \delta \omega \varsigma$ (Participle I knowing) and unwiss $<\mathrm{IE} .{ }^{*} n$-wid-tós (uncertain) and Gr. $\alpha$-i $\sigma$-tos $<n$-wid-tós (unknown). The verb has etymological parallels in all Germanic languages: Gt. wait (I know) corresponds to OHG. weiz, OSax. wèt, OE. wát, OIcel. veit. The verb does not have the present form in other Indo-European languages and it uses the perfect form for the present meaning. Gt. wait corresponds to Gr. Foī $\delta \alpha$, Skr. vēda, OSlav. ВБДБ (perfect optative) (I know). The main meaning of the root is to see (compare with Gr. $\varepsilon i \delta \omega$, L. video (I see), O Slav. ВИЖДЖ). The meaning of Gt. wait, Gr. Foī $\delta \alpha$ is the result of the action: I have seen that, and as a result I know that.

The fact that the verb wait is the form of the old perfect is confirmed by the root and ending structures. The verb root has a diphthong $a i<$ IE. $o i$ which interchanges with $-i$ - (zero grade) in the plural forms. The IE. vowel $-*^{*}$ - is the feature of the perfect forms, IE. $-e$ - is the feature of the present tense root. The comparison demonstrates tense forms: IE. present tense *weid-, perfect singular *woid-, perfect plural *wid-; Gr. present tense $(F) \varepsilon i \delta \omega$, perfect

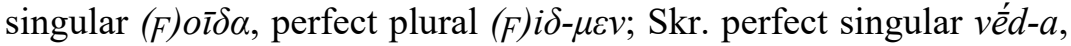
perfect plural vid-ma, OSav. present tense ВИЖДЖ, perfect singular ВБД-Ь, Gt. present tense in-weit-a, perfect singular wait, perfect plural wit-um. The vowel gradation in the perfect root (normative grade $-*^{*} i$-, zero grade $-*^{*}$-) is connected with the different stress in singular and plural forms, which is preserved in Sanskrit: vếda, but vidmá. In the Greek form Fi $\delta$ - $\mu \varepsilon v$ the root stress is secondary. The latter specific accentuation may be explained by the athematic conjugation of the Indo-European perfect. The ending of this verb is also the ancient Perfect ending.

The first person singular was represented in different languages: Gt. wait, Gr. $F o \overline{-}-\delta-\alpha$, Skr. vếd- $a$. The second person singular was

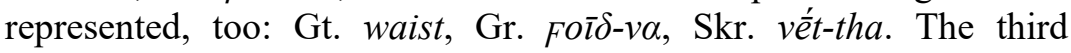


person singular is realised through the corresponding forms: Gt. wait, Gr. $F o \bar{l} \delta-\varepsilon$, Skr. vếd- $a$.

We consider it expedient to analyse the most significant verbs, which are called major ones (there are six of them: witan, kunnan, skulan, lais, oggan, paúrban). The first verb to be analysed, witan, has the root wit-um, which is used to form wit-an, wit-ands, wis-sa. Observing and investigating this problem it is necessary to take into account that the preterite-present verbs came into the Germanic lexical system. There was the coexistence of preterite-present verb witan with witan as a strong verb in Gothic [7, p. 476]. There were archaic participles weitwōpss, un-wiss, weak verbs fairwetjan (look out), witan (observe); compare L. vidēre.

The second verb to fall under the analysis is found in one form only, which calls for additional reconstruction. Gt. lais (I know) was preserved only in this form [17. p. 318 (Phi1 : 4, 12)]. This root was used to create Common Germanic causative GT. laisjan (scientist) and noun lists (cunning). All other Old Germanic languages have different meaning of list (knowledge, intellect, cunning). Weak verbs may have common roots with preterite-present ones. In this case there is a grammatical interchange: Gt. lais (I know): laisjan (to teach); OHG. leeren, OSax. lêrian, OE. leeran. If the structure of preteritepresent verbs is taken into consideration, it is evident that root vowel $i$ of basic verb (lais) and derivative one (laisjan) is the same.

The verb kunnan (know) could be arguably considered the most significant one among the major verbs. The past form kunpa and participle form kunpss draw attention. These forms occur in all Germanic languages. This common German form having a form making suffix $\hbar$ instead of traditional $\partial$ (compare Gt. munda) may help to explain the origin of Germanic weak preterite. This form is secondary but very archaic. According to Verner's law, Germ. $\not{p}$ might occur only after the initial stressed root syllable (IE. * $\left.{ }^{g} n-t o ̂-m\right)$, which being stressed could not be in the zero apophonic degree (there were such primary forms as * $\hat{g}$ en/góntzm or $* \hat{g} n-t o m)$. The secondary stress shift (from suffix to root) is known in other IndoEuropean languages. Compare Skr. vid-má with the primary stressed suffix and Gr. $F i \delta-\mu \varepsilon v$, it has the secondary stressed route 
with the zero degree. This preterite-present verb is the pattern of "centum" languages which are spoken on the periphery of IndoEuropean language area. The IE palatal * $\hat{g}$ is preserved in "centum" languages and is realised as $g$, but in "satem" languages is shifted into spirants $z, \check{z}$ or affricate [d $d_{3}$ (it is connected with the definite language): Gr. $\gamma i-\gamma v \omega ́ \sigma \chi \omega[\gamma<g$, $\hat{g}]$ (I recognise), L. (g)nốsco, Gt. kann $[k<g$, $\hat{g}]$ (I know), but OSlav. 3NATh, Lith. žinóti, Skr. jānáti (he knows) [5, p. 496].

Gothic nasal sonorants $[n],[\eta]$ occur in all positions in the word, but they have the tendency for doubling: kann (I know), which is an example of sonorant gemination. Weak verbs may have common root with the preterite-present ones, demonstrating definite grammatical interchange: Gt. kann (I know), kannjan (to announce); OHG. kann - kennen; OSax. kann - kennian; OE. con, cennan. Weak verbs create the past tense forms with the dental suffix - $\partial$ (IE. - *t-) with endings which in the singular of the Indicative Mood differ from the corresponding forms of strong preterite.

The origin of the weak past tense is still obscured. If we take into consideration endings, it could be supposed that the Germanic past tense is the Indo-European secondary aorist, which was created from the dental stem perfect participle of the Latin pattern ama-tu-s, mo-ni-tu-s (IE. - *tu-). This supposition is supported by the fact that Gothic weak verbs of the fourth weak conjugation are coined from the form of strong past participle [7, p. 204-211; 9, p. 167-169]. This fact is confirmed by the process of forming the past tense of preterite-present verbs when the suffix $-\bar{p}$ - is involved: Gt. kann: past tense kunбa (OE. cupe (I knew)). This phenomenon is Common Germanic. The comparison of Old Germanic languages demonstrates this: Gt. kun $\not a$, OHG. konda $(d<\bar{b})$, OSax. (past participle) $k u \delta(\delta=\not b)$, OE. cüpe. OIcel. kunna $(n n<n \bar{b})$. These facts show that the Germanic suffix of weak preterite $-ð$ - cannot originate from IE. $* d h$ and does not have anything in common with the verb root *dho/dhe. Interchange of kun-p-a : sōki-d-a (compare munda (I remembered)) shows that Indo-European prototype of this suffix $-* t$ - was that was split into two Germanic consonants $(\not, \delta)$ according to Verner's law. The interchange is proven by the difference in the stressed past tense 
forms of those verbs: kun̄a $<{ }^{*} g n-t \overline{-}-m$, sōkida $<{ }^{*}$ sog-i-tó-m. According to Kluge's theory, $[g]$ in Germanic preterite suffix sounded as -*tō-: $-* t \bar{e}-$ in IE environment. Gothic variant of this suffix déd- (sat-i-ded-um) was explained by Kluge by taking into consideration the form of second person plural. This form sounded as

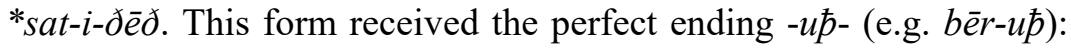
sat-i-déd-up. Later ending $-d \bar{e} d-$ spread among other forms according to analogy. The piling up of different suffixes (endings) which have the same meaning is a well-known phenomenon. OE. sind (she is) obtained ending -on: sindon according to the analogy of cunnon (they know). Kunnan forms archaic past participle kenps (known). It is formed according to the pattern peculiar of weak verb forms. They form past participle via the transformation: IE. - $-\bar{o}->$ Germ. $-* \partial a-$. Derivatives of this verb have durative meaning: uf-kunnan (past participle - kunnaida) (recognise), derived from kunnan (first person kunna) (know). Gt. kunळa as a preserved reflection of exception forms. The past tense of the verb, which was not found in Gothic, is formed similarly to kunta: OHG. an: onda, OE. an: útpe, OIcel. anna: unna (Germ. *an- : *un(kindness) and G. gunst [6, p. 328-331].

The fourth preterite-present verb in the major group is Đaúrban (to need) has past tense suffix -ta- (baúrfta), which is explained with the position after $-f$-; Germ. * $\not u r b-ð o$ was reflected in the Gothic language as paurfta. This verb occurred in other old Germanic languages: OHG. durfan, OSax. thurpan, OE. purfan, OIcel. purfa. Among widely spread word usage there is a frequent use of consonant $-f$ - in the final position of the word and before the final $s$ it may interchange with $b([b, \not b]$ நarf : நaúrbum. There is evidence that only one of the voiceless spirants $f, s, \chi, \chi w$ may go before -t-: pafr (I need) : parft (you need). There is also the interchange of labial consonants $b: f$ ( $b$ goes after consonant $f$, before $t$ ) paurban : Faurita. According to the process of Consonant Shift the Proto-Germanic language did not have these consonant clusters: $p t, k t$. This peculiarity of the consonant system was preserved in the historical period of the Germanic languages. This is very important for consonant clusters: plosive $+t$ or $d: p, f, \bar{p}$, 
$b+t, d>f t$, Gt. paúrfta (I needed): Gt. paúrbum (we need) $[f t<b+\delta]$. Grammatical interchange was preserved in the Gothic language only in the cases which did not form any system, for example, in the case of conjugation: $\not a f$ (I need): paúrbum (we need) $[f: b<f: \not b][7$, p. 374-375].

Germanic conjugation system, and Gothic in particular, preserves only separate features of the Indo-European perfect. Indo-European difference in the stress between singular, Indicative Mood, past tense and plural (the root is stressed in singular form, the suffix is stressed in plural form) was not preserved in the Germanic languages due to fixing the stress on the first (root) syllable of the verbs. According to Verner's law the reflection of this state is the grammatical interchange (voiceless spirants with voiced spirants in the final position of the word). This phenomenon occurred if the verb root in the Proto-Indo-European language in the final position had a voiceless consonant or *s (IE. *wert/wort, *wes/wos). The Gothic language did not preserve this phenomenon in the system of strong conjugation. Only two preterite-present verbs preserved this interchange: parf : நaúrbum (Germ. $f: \not \hbar$ ). There is archaic past participle taurfts (needed). It is a derivative of verb taúrban. This verb belongs to the third weak conjugation and is able to form reflexive verbs with durative meaning: ga-parban sik (restrain oneself). It is derived from paúrban (the first person parf) (need).

Grammatical significance and further analytisation of the Germanic languahes are connected with the fifth verb skulan (be obliged to) and corresponding archaic past participle skulds (indebted). This verb was found in other Old Germanic languages: OHG, OSax. scolan, OE. sculan, OIcel. skola. Other Indo-European languages have: Lith. skeliu (I owe), skolá (debt). This verb demonstrates the Indo-European vowel interchange that occurred in the roots of all the parts of speech (nouns, adjectives). In the Germanic languages, like in other related languages, this vowel interchange was preserved only in separate relics. It disappeared as a result of unification in different route variants.

Vowel interchange occurs in the roots of verbal nouns and adjectives (IE. ol : $\sigma l$ ): Gt. skal (I owe) : skula (debtor). This verb 
demonstrates the specifics of fricative voiced consonant, where $[\varnothing]$ (spelling $d$ ) is a voiced dental consonant, which stands is in opposition to voiceless $\bar{p}$, plosive $d$ and alveolar (postdental) fricative $z$. It may occur only in intervocal position. $Ð$ may interchange with $d$ and $t$ : skulda [d] (he owed) : aihta [t] (I had) [7, p. 45-48].

Gothic preterite-present verbs have an essential feature. It is a motivated consonant interchange. The most frequent one is the interchange of dental consonants according to the pattern: $\partial: d ; \partial$ : $\not ; \partial: a(z) ; d: t$. The central sound of this interchange is $\partial$, which is the oldest and least used consonant ( $z$ is the exception). This sound occurred only in the middle of the words, in intervocal position. Thus, there was past particple skulds (with $d$ that was transformed from $\partial$ after $l$ ) : nasi $\overline{\text { s }}$ (with $\bar{b}$ that was transformed from $\partial$ after vowel, before final $s$ ) : mahts (with $t$ that was transformed from $\delta$ after PG. $\gamma$ ). In those examples all consonants, which are involved into the interchange, originated from PG. $\partial$. In the Germanic language group this verb has a definite etymological parallels concerning the root structure, conjugation specifics. The form of the second person singular, indicative mood of those verbs has ending $-t$ in all Germanic languages (Gt. skalt, OHG. skalt, OSax. scalt, OE. scealt, OIcel. skalt). The same form of strong verbs in the West Germanic languages is absolutely different [11, p. 248].

The next preterite-present verb to be analysed is $\mathbf{0}$ gan (be afraid of). This verb was not found in other Germanic languages. Only in Old Icelandic was there a reflexive verb ó-ask (be afraid of), which was derived from this root. There are some difficulties in reconstructing the second person singular form. According to the phonetic law, the form ${ }^{*} \bar{o} h t$ (Germ. ${ }^{*} \gamma+t>h t$ ) should be recognised, but the existence of the form megt (from megan) makes us recognise the correct variant * $\overline{o g t}$. Imperative mood form $\overline{o g s}$ is obscure.

In the Gothic language there is a specific consonant interchange. It is caused by specific Gothic dissimilation of spirants in the unstressed syllables. If the unstressed (non-final, medial syllable) which has any spirant in the final position, has a voiceless consonant in the initial position, this spirant should be voiced $(\hbar, \delta, z)$. If a syllable has a voiced consonant in the initial position, the spirant 
should be voiceless $(f, \bar{f}, s)$. These examples demonstrate the unique spirant interchange in the unstressed syllables. This process was found only in the Gothic language: $(z: s)$ : hatiza (hatred) : agisa (fear), which all are the forms of Dative case singular. Gothic spirant $z$ interchanges with $s$ in a way that final $s$ corresponds to $z$ in the middle position (hatis - hatizis (hatred)). But there is a case when $s$ occurs in the middle position: agis : agisis (fear). There was a resemblance in the closed articulation of $\bar{o}$ and $u$. It is confirmed by the spelling of $u$ instead of $o$ : untēdum instead of $o g$ (be afraid of) $[17$, p. $285 ; 15$, p. 846]. The development of Gothic vowels was confirmed by the Silver Codex (Codex Argenteus) [15, p.1-70]. Short vowel of the high position $u$ reduces its position and transforms into $o$. This transformation $u>o$ happened in the early period. It is confirmed by the Gospel of St Luca text. The same transformation happened with $\bar{o}$. In Ulfilas' texts $\bar{u}$ is used instead of $\bar{o}: \bar{u} h t \bar{e} d u m[17$, p. 286] instead of ōhtēdum (be frightened by). This verb is connected with the sixth $(a-\bar{o}-\bar{o}-a)$ class of vowel gradation: agan (be afraid of). Weak verbs may have common root with the preterite-present verbs, demonstrating grammatical interchange: Gt. og (I am afraid of) : Gt. ogjan (scare). Verb $\bar{o} g$ has causative form ogjan. There is not only preterite-present verb ogan in the Gothic language. There is also strong verb *agan (compare with participle unagands (fearless)) [7, p. 36-37].

Conclusion. The results of the linguistic analysis prove that all preterite-present verbs as a separate type of verb group were formed in the Proto-Germanic period. Some verbs have certain correlations with other Indo-European (Romanic, Slavonic, Baltic) languages (witan, kunnan). Verb skulan has a vague correlation with the Lithuanian language. The rest of the verbs (lais, paúrban) were connected only with the Germanic language area. The involvement of Greek linguistic material helps to investigate all phonetic and grammar (morphological) processes that took place on the way of gradual forming of Germanic preterite-present verbs. IE. roots and Germanic innovations were found among them. They all together formed this hybrid verb class. The investigation of preterite-present 
verbs on the syntactic level, taking into consideration all sentence structures, appears promising and interesting.

\section{REFERENCES}

1. Bennet, W.H. (1980). An Introduction to the Gothic Language. New York: Modern Language Association [in English].

2. Braun, F. (1922). Die Urbevölkerung Europas und die Herkunft der Germanen. Berlin: Halle a.d. Saale [in German].

3. Braune, W. (1981). Gotische Grammatik. 19. Auflage. Tübingen: Max Niemeyer Verlag [in German].

4. Feist, S. (1924). Indogermanen und Germanen. Berlin: Halle a.d. Saale [in German].

5. Gamkrelidze, T. V. \& Vjaceslav V. Ivanov \& Jakobson, R. et al. (2010). Indo-European and the Indo-Europeans. A Reconstruction and Historical Analysis of a Proto-Language and Proto-Culture. Part I: The Text. Part II: Bibliography, Indexes. Berlin, Boston: De Gruyter Mouton [in English].

6. Heyne, M. (1906). Deutsches Wörterbuch. Berlin: Halle [in German].

7. Holthausen, F. (1934). Gotisches etymologisches Wörterbuch. Berlin: Halle a.d. Saale [in German].

8. Jellinek, M.H. \& Hermann, P. (2017). Geschichte der gotischen Sprache. Berlin, Boston: De Gruyter Mouton [in German].

9. Kluge, F. (1913). Ungermanisch. Strassburg: Halle. 348 s. [in German].

10. Lehmann, W. (1986). A Gothic Etymological Dictionary. Leiden, The Netherlands: Brill [in English].

11. Menge, H. \& Güthling, O. (1910). Menge-Güthling griechischdeutsches und deutschgriechisches Wörterbuch, mit besonderer Berücksichtigung der Etymologie. Berlin: Halle a.d. Saale [in German].

12. Mossé, F. (1949). Manuel de la langue gotique. Grammaire. Textes. Glossaire. Paris: Aubier [in French].

13. Plotkin, V. (2008). The Evolution of Germanic Phonological Systems: Proto-German, Gothic, West Germanic and Scandinavian. Lewiston, N.Y.: Edwin Mellen Press [in English].

14. Rauch, I. (2003). The Gothic language: grammar, genetic provenance and typology, readings. New York: P. Lang [in English].

15. Snædal, M. (1998). A Concordance to Biblical Gothic. Reykjavík: Institute of Linguistics, University of Iceland; University of Iceland Press. Vol. 1. Introduction. Texts; p. 70. Vol. 2, Concordance [in English]. 
Актуальні проблеми української лінгвістики: теорія і практика

16. Voyles, J.B. (1992). Early Germanic Grammar: Pre-, Proto-, and Post-Germanic Languages. San Diego, California: Academic Press [in English].

17. Wright, J. (1997). Grammar of the Gothic Language. 2nd ed. Oxford: Clarendon Press [in English].

18. Wright, J. \& Wright, E.M. (1925). Old English Grammar (3rd edition). London: Oxford University Press [in English].

Дата надходження до редакції - 28.09.2019 Дата затвердження редакцісю - 07.10.2019 